\title{
Morphological variability, spatial distribution and abundance of Helicostomella species (Ciliophora: Tintinnina) in relation to environmental factors (Argentine shelf; $40-55^{\circ} \mathrm{S}$ )
}

\author{
LUCIANA F. SANTOFERRARA ${ }^{1,2}$ and VIVIANA A. ALDER ${ }^{1,2,3}$ \\ ${ }^{1}$ Departamento de Ecología, Genética y Evolución, Facultad de Ciencias Exactas y Naturales, Universidad de Buenos \\ Aires, C1428EHA, Buenos Aires, Argentina. E-mail: lusantoferrara@ege.fcen.uba.ar. \\ ${ }^{2}$ Consejo Nacional de Investigaciones Científicas y Técnicas, Av. Rivadavia 1917, C1033AAJ, Buenos Aires, Argentina. \\ ${ }^{3}$ Instituto Antártico Argentino, Cerrito 1248, C1010AAZ, Buenos Aires, Argentina.
}

\begin{abstract}
SUMMARY: For the first time a taxonomic and ecological study of species belonging to Helicostomella was performed over a mesoscale spatial distribution by examining ca. 3000 loricae collected in Argentine shelf waters during the austral autumn. Microscopic and statistical analysis revealed that the general shape and the oral diameter remained practically constant in the whole area surveyed, despite a continuous length fluctuation of ca. $300 \mu \mathrm{m}$, which includes the entire range present in eight previously reported species. Consequently, we consider that the genus may be represented only by $H$. subulata, whose strong fluctuations in length (mostly attributed to an increase in the collar length), density and biomass seem to respond to temperature, food availability and front-related processes. In Buenos Aires coastal waters associated with a quasi permanent estuarine front $\left(40-40.5^{\circ} \mathrm{S}\right)$, mixed conditions would favour moderate abundances of long loricae, whereas in northern (42.5$\left.45.5^{\circ} \mathrm{S}\right)$ and southern $\left(46-54.5^{\circ} \mathrm{S}\right)$ Patagonian waters, high $\left(10^{3}\right.$ ind. $\left.\mathrm{L}^{-1}\right)$ and low $\left(<5\right.$ ind. $\left.\mathrm{L}^{-1}\right)$ densities of short loricae seem to be a consequence of stratification and encystment, respectively. The non-occurrence of the species at $41-42^{\circ} \mathrm{S}$, together with a three-fold reduction in length-related parameters between specimens from Buenos Aires and Patagonian waters, suggests a disjunct distribution.
\end{abstract}

Keywords: tintinnids, genus Helicostomella, lorica polymorphism, abundance, shelf dynamics, fronts, environmental factors.

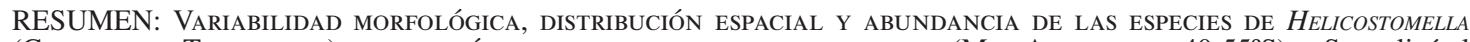

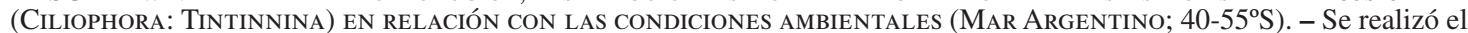
primer estudio taxonómico y ecológico de mesoescala sobre las especies del género Helicostomella, examinando ca. 3000 lórigas colectadas en el Mar Argentino durante el otoño austral. Los análisis microscópicos y estadísticos revelaron que la forma general de la lóriga y su diámetro oral permanecen prácticamente constantes en toda el área analizada, mientras que su longitud presenta una variación de ca. $300 \mu \mathrm{m}$, incluyendo todo el rango correspondiente a 8 especies previamente reportadas. En consecuencia, el género estaría representado por una única especie, $H$. subulata, cuyas variaciones en longitud (atribuidas principalmente a la longitud del cuello), densidad y biomasa responderían a la temperatura, disponibilidad y calidad del alimento y procesos frontales. En aguas costeras de Buenos Aires asociadas a un frente estuarino casi permanente (40-40.5 $\mathrm{S})$, las condiciones de mezcla favorecerían el desarrollo de lórigas largas en abundancias moderadas, mientras que en aguas del Norte $\left(42.5-45.5^{\circ} \mathrm{S}\right)$ y del Sur $\left(46-54.5^{\circ} \mathrm{S}\right)$ de la Patagonia prevalecen lórigas cortas en densidades elevadas $\left(10^{3}\right.$ ind. $\left.\mathrm{L}^{-1}\right)$ o muy bajas $\left(<5\right.$ ind. $\left.\mathrm{L}^{-1}\right)$ como consecuencia de procesos de estratificación y enquistamiento, respectivamente. La no detección de la especie entre $41-42^{\circ} \mathrm{S}$, junto con la reducción en 3 veces de los parámetros relacionados con la longitud entre especímenes de las aguas de Buenos Aires y las Patagónicas, sugiere una distribución separada entre ambas áreas.

Palabras clave: tintínidos, género Helicostomella, polimorfismo de la lóriga, abundancia, dinámica de plataformas marinas, frentes, factores ambientales. 


\section{INTRODUCTION}

While it is currently accepted that tintinnid taxonomy needs to be complemented with cytological and/or molecular analyses, up to date this kind of information is available only for fewer than 30 tintinnid species (Agatha and Strüder-Kypke, 2007). This represents approximately $5 \%$ of the total species included in the most widely used classification system (Kofoid and Campbell, 1929, 1939), which encompasses hundreds of taxa often distinguished on the basis of minute variations in the shape, size and details of the lorica. The latter structure has the advantage of being easily preserved and providing features that facilitate the identification of species in either strictly taxonomic or ecological studies, thus persisting until today as the main tool for tintinnid taxonomy. However, the lorica of many species shows a high degree of polymorphism which responds to the life cycle and the environmental conditions, with the oral diameter being perhaps the only attribute with true diagnostic value (Gold and Morales, 1975; Laval-Peuto, 1981; Laval-Peuto and Bronwlee, 1986; Alder, 1999).

According to the scheme proposed by Kofoid and Campbell (1929, 1939), the genus Helicostomella comprises five species. A literature review later performed by Alder (1999) on South Atlantic tintinnids, however, led to the conclusion that both the constancy of the oral diameter and the continuity of the lorica length make it impossible to establish a cutting point between species previously reported as belonging to the genus, for which reason they should be considered as synonyms of $H$. subulata. Regardless of such opposite systematic criteria, the major limitation for both cases is the fact that their conclusions emerge only from the revision of previous descriptions, as up to date there have been practically no field studies focusing on the relationships between the morphological variability of this species and environmental forces.

The genus Helicostomella has a worldwide neritic distribution (Pierce and Turner, 1993). Within this genus, $H$. subulata is the species most frequently reported in ecological studies and one of the most abundant, especially from spring to autumn, when it often dominates over other tintinnids (Wasik and Mikolajczyc, 1996; Bojanić et al., 2006; Nakane et al., 2008), and occasionally over the rest of the microzooplanktonic components (Paranjape, 1987; Kim et al., 2007). During winter, H. subulata prac- tically disappears from the water column, probably due to cyst formation and sedimentation (Paranjape, 1980). Because of its abundance levels and the size of its lorica, the species is assumed to be an important food item for larger zooplankton (Pierce and Turner, 1992) and to consume mainly pico- and nanoplankton (Bernard and Rassoulzadegan, 1993; Dolan et al., 2002), thus playing a major role in pelagic neritic food webs. However, neither the species nor the genus has been studied to date at the mesoscale level from the ecological point of view.

Argentine shelf waters are one of the largest neritic environments in the world (ca. $10^{6} \mathrm{~km}^{2}$ ), extending from $36^{\circ} \mathrm{S}$ to $55^{\circ} \mathrm{S}$ and characterised by a strong seasonality. Tidal forces and physico-chemical gradients generate well-defined fronts (Acha et al., 2004; Bianchi et al., 2005), which concur with high levels of chlorophyll $a$ (Romero et al., 2006), large biomass of zooplankton (Sabatini and Álvarez Colombo 2001; Sabatini and Martos, 2002) and fishery resources (Boschi, 1998). This shelf is dominated by the nutrient-enriched, saline, subantarctic waters of the Malvinas/Falkland Current (Fig. 1), but in its southernmost sector it also receives the strong influence of less saline waters via the Cape Horn Current and through the Strait of Magellan. In its northern and middle sectors, the Río de la Plata estuary and several other rivers further contribute to the dilution of coastal waters (Piola and Rivas, 1997).

In this context, considering that several species of Helicostomella were originally described for the area (Balech 1942, 1951; Souto 1970 a,b), we can predict that an environment highly heterogeneous in space and time such as that of Argentine shelf waters will display the entire range of variability of Helicostomella and will thus be suitable for examining how the environment influences the lorica morphology and determining whether the different forms should be grouped under distinct species or rather under the single species $H$. subulata. This work is thus intended to statistically analyse the quali-quantitative spatial distribution of Helicostomella along a transect of ca. 14 degrees of latitude extending from coastal to inner shelf waters, in relation to autumn conditions of temperature, salinity and chlorophyll $a$.

\section{MATERIALS AND METHODS}

Thirty oceanographic stations with a spatial resolution of $0.5^{\circ}$ latitude were performed on board the 


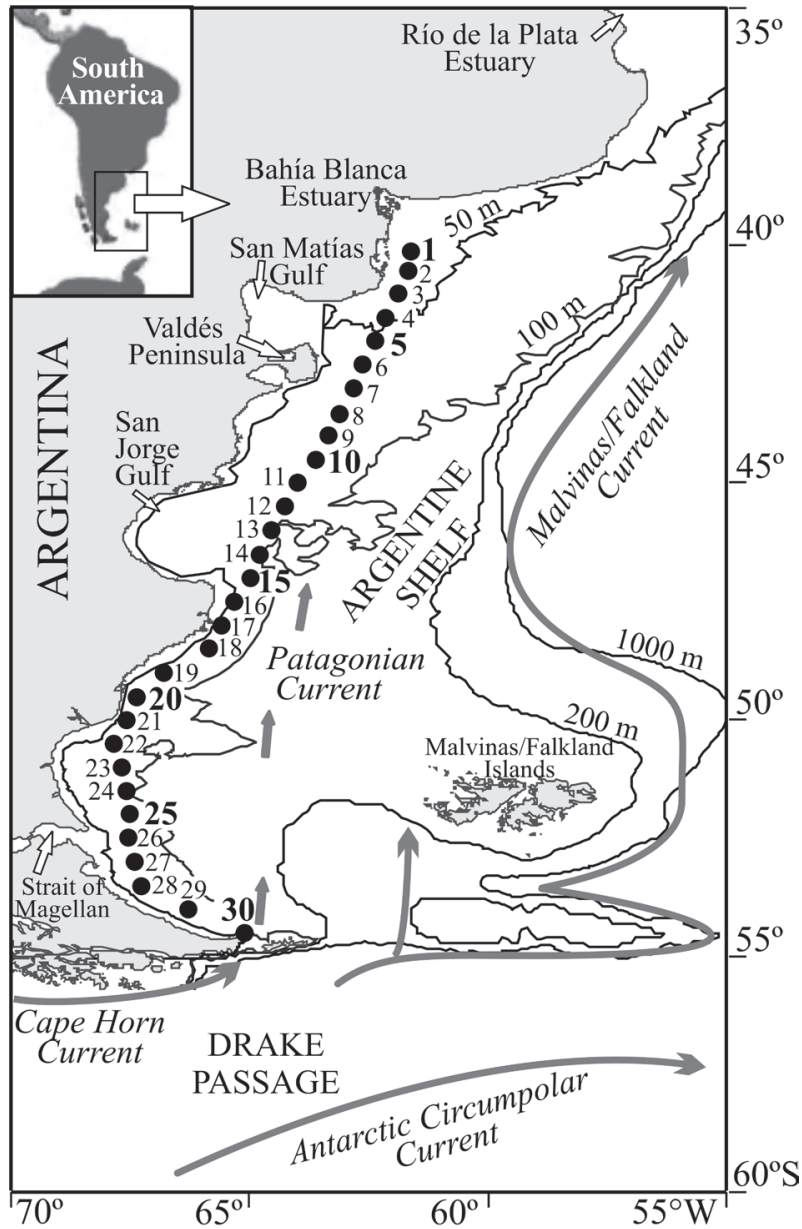

FIG. 1. - Area studied. Arrows and circles indicate general circulation of the main currents and the location of oceanographic stations, respectively.

icebreaker Almirante Irizar in Argentine shelf waters between $40^{\circ} \mathrm{S}$ and $54.5^{\circ} \mathrm{S}$ from 10 to 12 April 2002 (Fig. 1). At each station, sub-surface (9 m) seawater samples provided by a centrifugal pump were collected for the analysis of plankton, nutrients and chlorophyll $a$ concentration. Seawater temperature and salinity were measured by a continuous sampling system from the same depth and water source using the Sea-Bird SB 38 and 37 sensors, respectively, in the framework of the ARGAU Project.

Plankton samples were treated according to two different procedures: (1) ca. $200 \mathrm{~L}$ of water was filtered through a sieve ( $20 \mu \mathrm{m}$ of pore size) and fixed with $50 \%$ f.c. Bouin solution ("filtered samples"); (2) $0.5 \mathrm{~L}$ of unfiltered water was fixed with $20 \%$ f.c. Bouin's solution ("non-filtered samples"). Nutrient samples $(50 \mathrm{~mL})$ were stored at $-20^{\circ} \mathrm{C}$ and later analysed for nitrate and nitrite concentration with an autoanalyser using standard colorimetric techniques (Strickland and Parsons, 1972). For chlorophyll $a$ de-

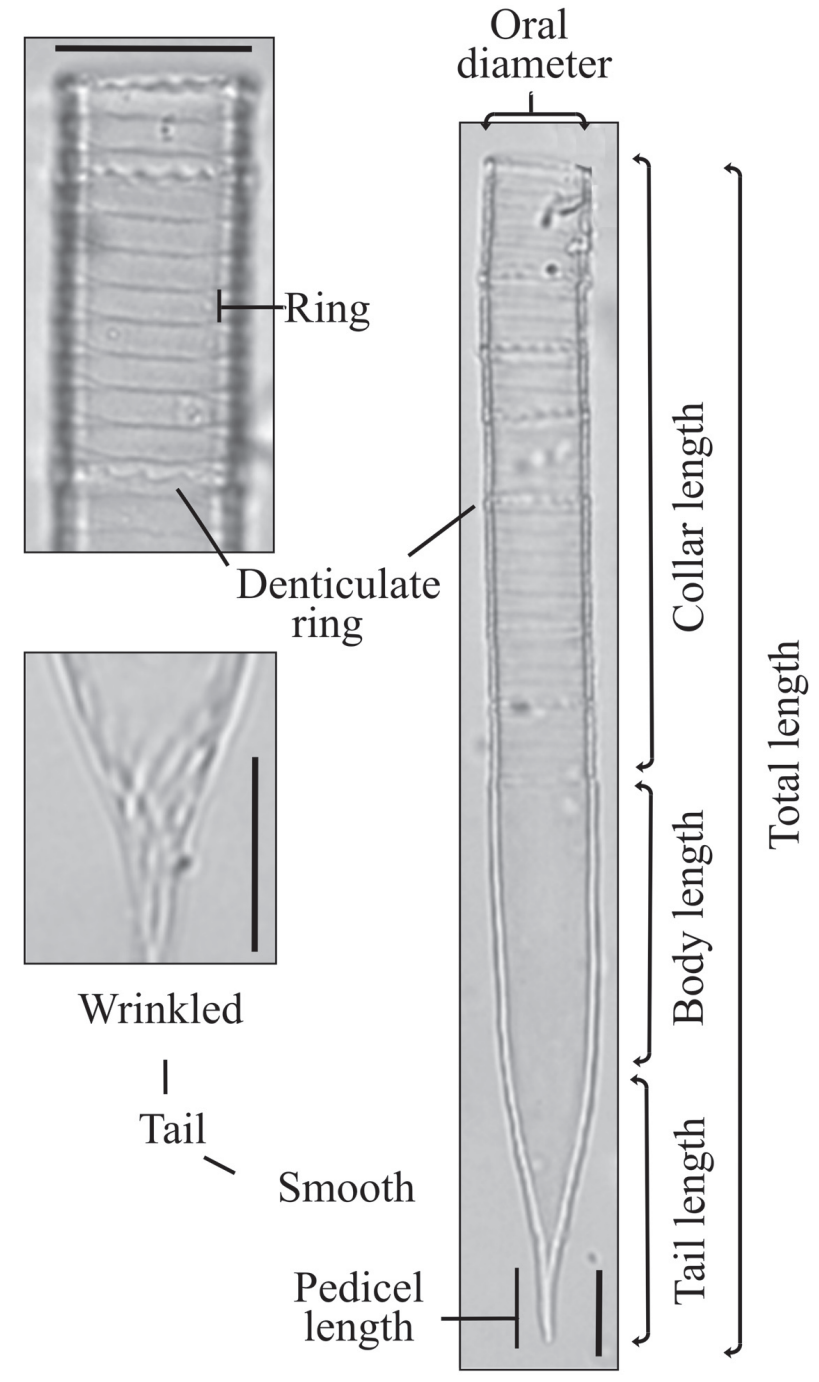

FIG. 2. - Morphological features examined on the lorica of Helicostomella specimens. Bar $=20 \mu \mathrm{m}$.

terminations, ca. $3 \mathrm{~L}$ of seawater was filtered onboard through a Whatman GF/F filter and stored in the dark at $-20^{\circ} \mathrm{C}$; each filter was later allowed to extract in $90 \%$ acetone for 24 hours. Chlorophyll $a$ was measured by a spectrophotometer, following the standard procedure of Strickland and Parsons (1972).

Approximately 3000 individuals of Helicostomella from both series of plankton samples were examined as to their lorica morphology. A minimum of 10 specimens (total: 332) were randomly selected from each filtered sample and measured under an upright microscope $(1000 \times)$. Nine morphological features were evaluated on each lorica: seven length-related parameters (total length, collar length, body length, tail length, pedicel length, number of rings, and number of denticulate rings), the oral diameter, and the presence/absence of wrinkles in the tail (Fig. 2). Biovolume was calculated 
by approaching the shape of the lorica to a cylinder attached to a cone, corresponding to the collar plus the body and the tail, respectively.

Total and cell/cyst-bearing loricae in the two series of samples were counted under an inverted microscope (Utermöhl, 1958). Three to four sedimentation chambers of 10 or $25 \mathrm{~mL}$ were examined per sample in order to reach a minimum of 100 counted individuals and a resulting maximum relative error of ca. 30\%. Since most of the non-filtered samples did not allow such numbers to be reached, these were disregarded for quantitative analysis. Biomass at each station was estimated by the equation:

\section{pg $C$ ind $^{-1}=$ lorica biovolume $\times 0.053+444.5$}

(Verity and Langdon, 1984).

Two non-metric multi-dimensional scaling (MDS) plots were performed using Bray-Curtis' dissimilarity matrices (Field et al., 1982), one to ordinate all examined specimens on the basis of the nine morphological features measured (MDSa), and one to ordinate the 27 stations with occurrences of Helicostomella on the basis of the mean value obtained for each morphological feature (MDSb). A standardised principal component analysis (PCA) based on a cross-product correlation matrix was performed to arrange all 30 stations on the basis of temperature, salinity, bottom depth, nitrate and nitrite concentrations. Further statistical analyses included a KruskalWallis' ANOVA $(\alpha=0.05)$ based on morphological parameters aimed at establishing whether the groups of stations arising from MDSb were significantly different; non-parametric correlation analyses (nontransformed data; Spearman's coefficient; $\alpha=0.05$ ) between morphological parameters/abundance values of Helicostomella and environmental variables, both along the entire transect and within a group of stations; and a Friedman's ANOVA $(\alpha=0.05)$ for contrasting density estimations from three sets of paired filtered vs. non-filtered samples (only those for which the latter yielded statistically significant counts), in order to determine whether filtration led to underestimation.

\section{RESULTS}

The complete range of variability observed for the loricae of Helicostomella is shown in Figure 3. The lorica has a cylindro-conical shape and a hyaline

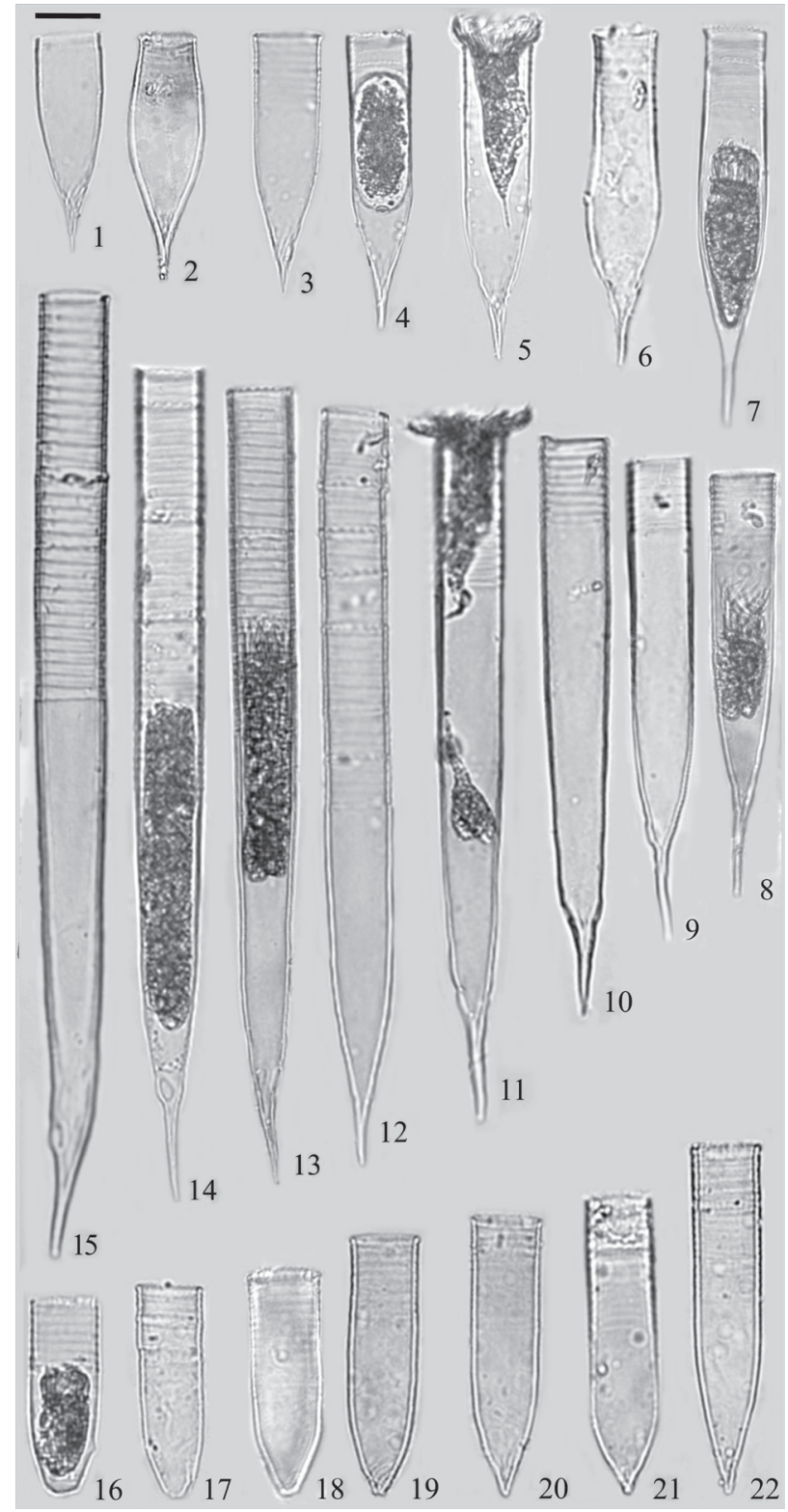

FIG. 3. - Variability of the loricae of Helicostomella in Argentine shelf. Bar $=20 \mu \mathrm{m}$.

wall which can be either smooth or wrinkled at its terminal end (specimens 12 and 1, 3 and 19, respectively). The mean value found for the oral diameter was $20.5 \mu \mathrm{m}$, with fluctuations in the range of 18 to $24 \mu \mathrm{m}$. The total length, which can be divided into a collar, a body and a tail, ranged between 56 and $384 \mu \mathrm{m}$. The collar length was observed to range between 2 and $236 \mu \mathrm{m}$, and to consist of 1 to 64 rings. The outermost ring (oral rim), and occasionally some intermediate ones, may bear small teeth. Epiloricae (blocks of rings), when present, never exceeded seven in number, and were generally limited by denticulate rings (specimen 12). The body length 

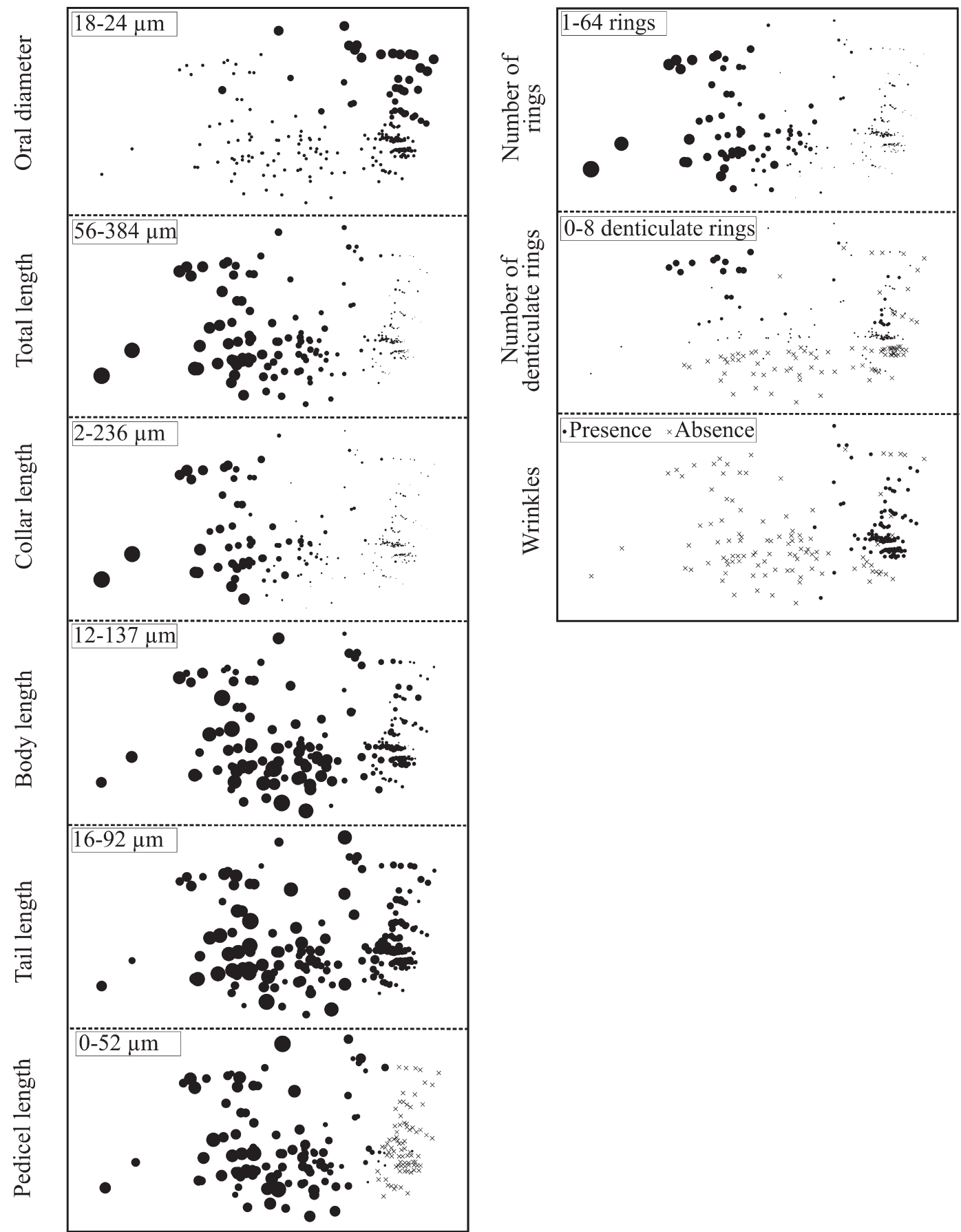

FIG. 4. - Multi-Dimensional Scaling ordination of Helicostomella loricae based on the nine morphological parameters examined, with bubble plots superimposed for each variable. Each bubble represents a single specimen, and its size is proportional to the value measured. Crosses indicate absence of the character.

and tail length varied from 12 to $137 \mu \mathrm{m}$ and from 16 to $92 \mu \mathrm{m}$, respectively. In the great majority of the specimens examined, the maximum diameter of the body matched the oral diameter; a few individuals, however, showed a slight expansion $(<4 \mu \mathrm{m})$ in the middle part of the body (specimens 2 and 6 ). While some specimens exhibited a pedicel of up to $48 \mu \mathrm{m}$ (specimens 8-15), others had an acute (specimens 1-
7), conical (specimens 18-22) or rounded (specimens $16,17)$ terminal end. Biovolume values showed strong variations (from $1.1 \times 10^{4}$ to $10.6 \times 10^{4} \mu \mathrm{m}^{3}$ ), with mean contributions of the collar, body and tail of $50 \%, 35 \%$ and $15 \%$, respectively.

The ordination of specimens on the basis of morphological features (MDSa; Fig. 4, stress $=0.09$ ) resulted in a single cloud of points without isolated 
TABLE 1. - Morphological parameters of Helicostomella for stations and groups of stations obtained from the Multi-Dimensional Scaling plot shown in Figure 5. SD: Standard deviation; a: $\mu \mathrm{m}$; b: $10^{4} \mu \mathrm{m}^{3}$.

\begin{tabular}{|c|c|c|c|c|c|c|c|c|c|c|c|c|c|c|c|c|}
\hline \multirow[b]{2}{*}{ Parameter } & \multicolumn{16}{|c|}{ Stations } \\
\hline & Min & $\begin{array}{r}1 \\
\operatorname{Max}\end{array}$ & $\begin{array}{l}-2 \\
\text { Mean }\end{array}$ & SD & $\begin{array}{c}\text { 6-1 } \\
\text { Min }\end{array}$ & $\begin{array}{r}6,18, \\
\operatorname{Max}\end{array}$ & $\begin{array}{l}19,21 \\
\text { Mean }\end{array}$ & -30 & Min & $\begin{array}{c}1 \\
\operatorname{Max}\end{array}$ & $\begin{array}{l}7 \\
\text { Mean }\end{array}$ & SD & Min & ${ }_{\operatorname{Max}}^{2}$ & Mean & SD \\
\hline Oral diameter & 20 & 22 & 20.1 & 0.4 & 18 & 24 & 20.4 & 1.2 & 19 & 24 & 21.7 & 1.8 & 20 & 24 & 21.6 & 2.1 \\
\hline Total length ${ }^{\mathrm{a}}$ & 108 & 384 & 236 & 53.7 & 56 & 144 & 88 & 17.8 & 68 & 208 & 136 & 42.6 & 68 & 168 & 92 & 36 \\
\hline Collar length ${ }^{\mathrm{a}}$ & 12 & 236 & 92 & 51.2 & 2 & 48 & 20 & 7.1 & 12 & 60 & 33 & 15.3 & 16 & 48 & 22 & 10.9 \\
\hline Body length ${ }^{\mathrm{a}}$ & 48 & 137 & 85 & 21.8 & 12 & 68 & 31 & 10.4 & 32 & 118 & 59 & 23.8 & 16 & 76 & 32 & 21.1 \\
\hline Tail length ${ }^{\mathrm{a}}$ & 28 & 92 & 59 & 15.7 & 16 & 72 & 37 & 8.8 & 20 & 84 & 48 & 17.7 & 28 & 48 & 38 & 5.4 \\
\hline Pedicel length ${ }^{\mathrm{a}}$ & 8 & 48 & 31 & 6.8 & 0 & 20 & 1 & 3.4 & 0 & 52 & 20 & 17.0 & 0 & 16 & 3 & 6.7 \\
\hline N. of rings & 3 & 64 & 23 & 12.3 & 1 & 12 & 6 & 2.1 & 4 & 20 & 11 & 6.0 & 4 & 12 & 6 & 3.0 \\
\hline N. denticulate rings & 0 & 8 & 2.1 & 1.5 & 0 & 3 & 0.8 & 0.7 & 0 & 2 & 0.5 & 0.6 & 0 & 2 & 0.6 & 0.7 \\
\hline Biovolume $\mathrm{e}^{\mathrm{b}}$ & 2.7 & 10.6 & 6.0 & 1.7 & 1.1 & 4.3 & 2.1 & 0.5 & 1.7 & 7.1 & 3.8 & 1.4 & 1.4 & 6.0 & 2.5 & 1.6 \\
\hline
\end{tabular}

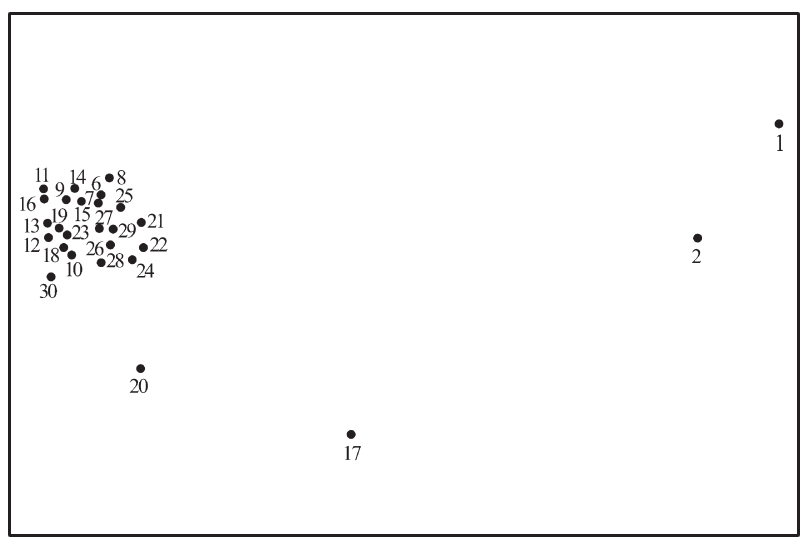

FIG. 5. - Multi-Dimensional Scaling ordination of stations based on the mean value of each morphological parameter measured on Helicostomella.

clusters, thus suggesting the continuity of values for each parameter considered. While all length-related parameters were found to follow the same trend as the total length, bubble plots reflect, firstly, the correspondence between longer individuals (whose greater length is due basically to an increase in the collar length and the number of rings) and those with a smaller oral diameter, and, secondly, the association of short loricae with those wrinkled at the terminal end.

The ordination of stations according to the mean value of each morphological feature (MDSb; Fig. 5 , stress $=0.02$ ) reveals that all but four stations (St. 1, 2, 17 and 20) host morphologically similar individuals. Morphological data corresponding to the main groups of stations and the sites differentiated in MDSb are summarised in Table 1. While no significant differences were detected regarding the oral diameter (Kruskall-Wallis' test; $P>0.25$ ), the values of length-related parameters (LRP) were significantly higher at St. $1-2$ and $17 \quad(P<0.009)$. Considering the total length, the mean values found at St. 1-2 and St. 17 were ca. three and two times longer, respectively, than the average estimated for the remaining sites, although there was an overlapping in the ranges recorded for successive stations (Fig. 6A). Furthermore, most of the loricae from St. 1-2 showed a smooth texture along the tail, while over $80 \%$ of those from the other stations (St. 6-30) had wrinkles. These two sectors were separated by a gap in the distribution of Helicostomella (St. 3-5), where no occurrences were detected (Fig. 6B).

The quantitative analysis of the 30 sets of paired (filtered vs. non-filtered) samples revealed that Helicostomella was not present in $0.5 \mathrm{~L}$ of non-filtered water whenever its density (estimated through filtered samples) fell below 20 ind. $\mathrm{L}^{-1}$ (20 stations; Fig. 6B). In addition, most of the remaining non-filtered samples contained far fewer than 100 specimens, thus preventing us from obtaining statistically significant results. Density estimations from filtered vs. non-filtered samples could therefore be compared only for St. 8, 9 and 11, where concentrations were over 1000 ind. $\mathrm{L}^{-1}$. At these three stations, the loricae registered in both types of sample were similar as to their total length $(56-144 \mu \mathrm{m})$ and oral diameter $(18-24 \mu \mathrm{m})$, but denoted significant (Friedman's test; $P<0.002$ ) underestimations of $46 \%, 23 \%$ and $35 \%$, respectively, due to filtering. Although this information is admittedly too scarce to calculate a correction factor for filtered samples (from which a total of 2800 individuals were counted), the data set as a whole seems to be consistent enough to reflect the actual distribution and abundance trends of Helicostomella.

Average density and biomass values estimated for Helicostomella were 143 ind. $\mathrm{L}^{-1}$ and $0.22 \mu \mathrm{g} \mathrm{C} \mathrm{L} \mathrm{L}^{-1}$, respectively. The highest abundance values were recorded at $44^{\circ} \mathrm{S}$ (St. 9: 1872 ind. $\mathrm{L}^{-1}$ and $2.94 \mu \mathrm{g} \mathrm{C} \mathrm{L} \mathrm{L}^{-1}$; Fig. 6B). Almost all (94\%) the individuals examined corresponded to empty loricae. Cell-bearing loricae 


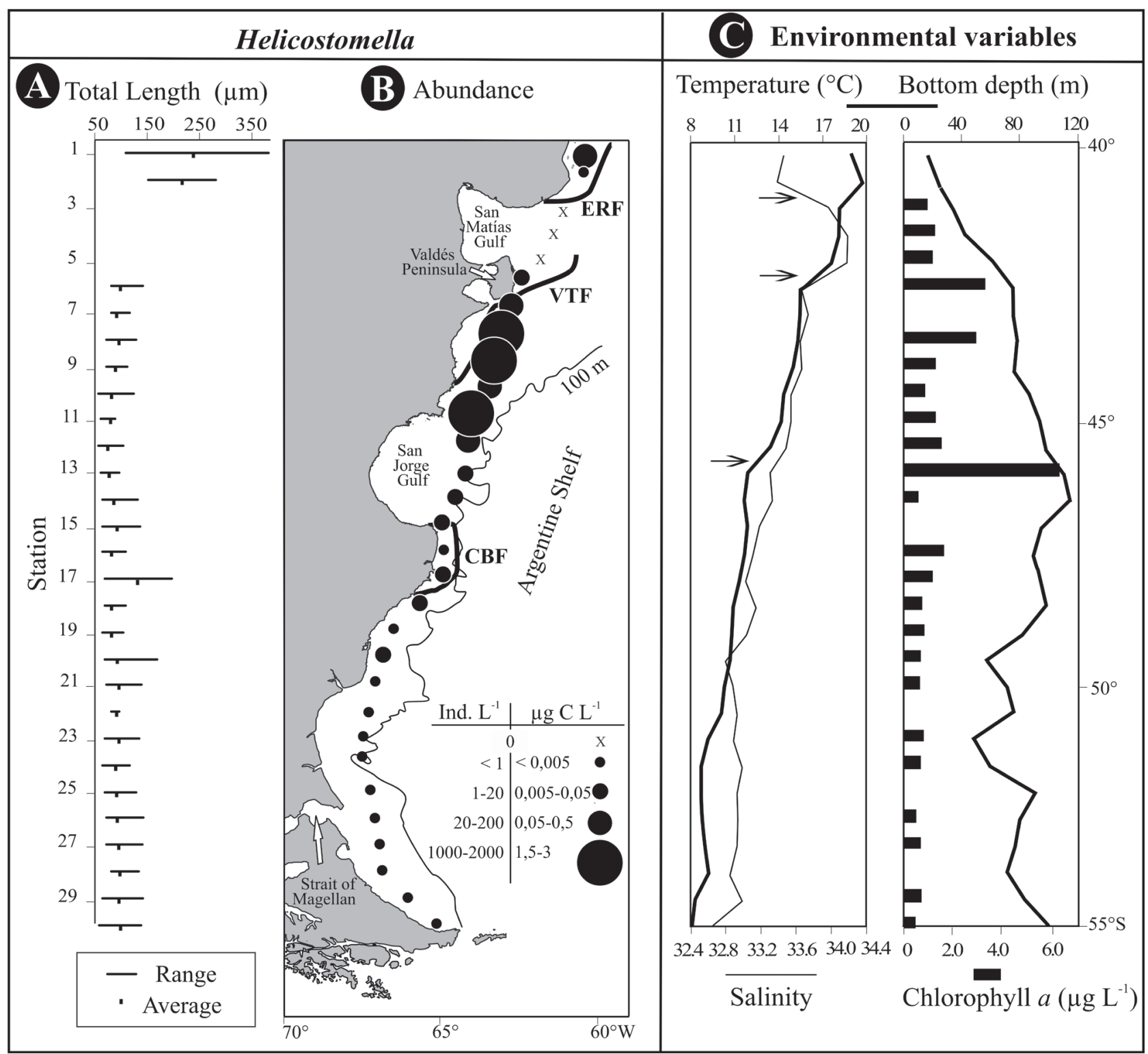

FIG. 6. - Latitudinal fluctuations of lorica length and abundance of Helicostomella, and environmental variables in the area studied. (A) Mean value and range of total length. (B) Density and biomass. Lines denote historical position of fronts: El Rincón front (ERF), Blanco Cape front (CBF) and Valdés front (VF) (Sabatini and Martos, 2002; Acha et al., 2004). (C) Temperature, salinity, bottom depth and chlorophyll $a$ concentration. Arrows indicate latitudinal gradients of temperature and salinity.

(Fig. 3, specimens 5, 7, 8, 11, 13, 14, 16) were found in densities below 79 ind. $\mathrm{L}^{-1}$ (mean: 9 ind. $\mathrm{L}^{-1}$ ), representing $40 \%$ of total loricae at St. 1-2 and between $1 \%$ and $12 \%$ at St. $6-13,17-21$ and 25 . At the rest of the stations (most of them located in the southern sector of the area surveyed) all loricae examined were empty. Cysts were found only at St. 9, with low density (4 cysts L ${ }^{-1}$; Fig. 3, specimen 4 ).

The profiles of temperature and salinity (Fig. $6 \mathrm{C})$ showed a southward decrease (from $20^{\circ} \mathrm{C}$ to $8^{\circ} \mathrm{C}$ and from 34.2 to 32.5 , respectively), in concurrence with an inverse trend in the concentration of nitrate and nitrite, which reached maxi- mum values of $9.41 \mu \mathrm{M}$ and $1.02 \mu \mathrm{M}$ at $54.5^{\circ} \mathrm{S}$ and $49.5^{\circ} \mathrm{S}$, respectively (data not shown). Chlorophyll $a$ concentration was generally low, clearly peaking at $42.5-43.5^{\circ} \mathrm{S}\left(2.93-3.30 \mu \mathrm{g} \mathrm{L}^{-1}\right)$ and at $46^{\circ} \mathrm{S}$ (Max: $6.30 \mu \mathrm{g} \mathrm{L}^{-1}$ ). Bottom depth varied from 16 $\mathrm{m}$ to $112 \mathrm{~m}$, with most of the stations located in the range of $50-100 \mathrm{~m}$. The results from the PCA (Fig. 7) showed that temperature, salinity and nitrate were the main variables on the first axis ( $66 \%$ of total variance; $\mathrm{Ev}=0.51,0.49$ and -0.51 , respectively), while on the second axis the highest weight was represented by bottom depth and nitrite $(17 \%$ of total variance; $\mathrm{Ev}=-0.83$ and 0.43 , 


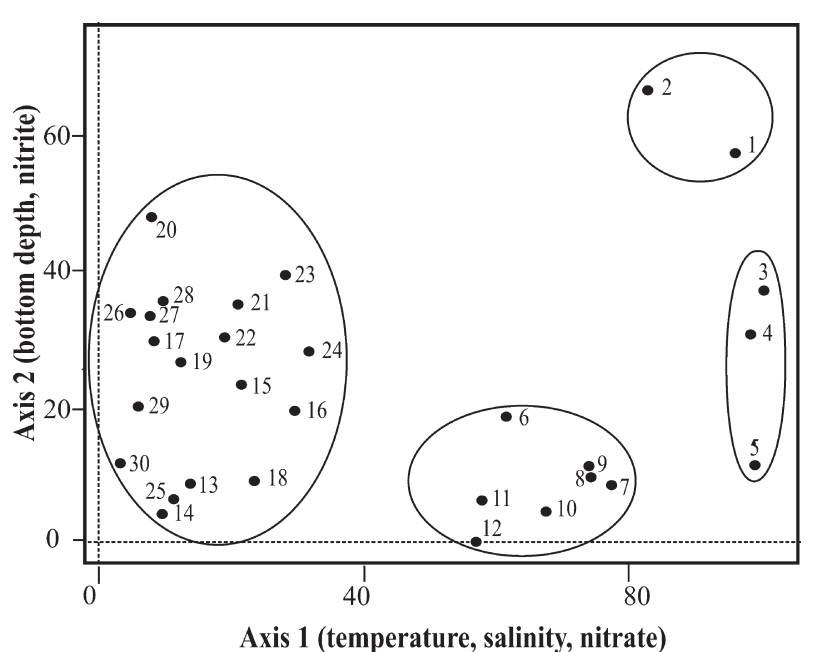

FIG.7. - Representation of a Principal Component Analysis of stations based on environmental variables.

respectively). This analysis displayed four groups of stations: St. $1-2\left(40-40.5^{\circ} \mathrm{S}\right)$, St. 3-5 (41-42 $\left.\mathrm{S}\right)$, St. 6-12 (42.5-45.5 $\mathrm{S})$ and St. $13-30\left(46-54.5^{\circ} \mathrm{S}\right)$, the limits of which were noted to match with steep changes in the latitudinal profiles of temperature and salinity found at $40.5-41^{\circ} \mathrm{S}, 42-42.5^{\circ} \mathrm{S}$ and 45.5-46 ${ }^{\circ} \mathrm{S}$ (Fig. 6C).
The confrontation of the arrays of stations obtained on the basis of the morphology of Helicostomella (MDSb, Fig. 5) and the environmental variables (PCA, Fig. 7) revealed that: (1) the northernmost St. 1-2 break apart in both analyses; (2) St. 3-5 form a separate group in the PCA, and correspond to the sector where Helicostomella was not recorded (Fig. $6 \mathrm{~B})$; and (3) practically all the remaining stations appear as linked in MDSb (except for St. 17 and 20) but constitute two separate groups in the PCA (St. 6-12 and 13-30). These two groups of stations have clearly different levels of Helicostomella abundance (Fig. 6B). The features observed for each of these four groups of stations are indicated in Table 2.

The correlation analysis involving the morphological variables of Helicostomella at the 27 stations hosting the species (Table 3) yielded significant levels $(P<0.05)$ of inverse covariation for bottom depth (vs. six length-related parameters and biovolume) and, secondarily, for chlorophyll $a$ (vs. oral diameter, pedicel length and biovolume). Significant direct covariations were obtained only for temperature vs. collar length. Abundance parameters, on the other hand, were found to show a significant direct

TABLE 2. - Environmental variables and abundance ranges of Helicostomella for groups of stations derived from the Principal Component Analysis shown in Figure 7. ND: not detected.

\begin{tabular}{|c|c|c|c|c|c|c|c|c|c|c|c|c|}
\hline \multirow[b]{3}{*}{ Parameter } & \multicolumn{12}{|c|}{ Stations/ Latitude } \\
\hline & \multicolumn{3}{|c|}{$\mathbf{1 - 2}\left(40-40.5^{\circ} \mathrm{S}\right)$} & \multicolumn{3}{|c|}{ 3-5 $\left(41-42^{\circ} \mathrm{S}\right)$} & \multicolumn{3}{|c|}{ 6-12 (42.5-45.5요 } & \multicolumn{3}{|c|}{$\mathbf{1 3 - 3 0}\left(46-54.5^{\circ} \mathrm{S}\right)$} \\
\hline & Min & Max & Mean & Min & Max & Mean & Min & Max & Mean & Min & Max & Mean \\
\hline Temperature $\left({ }^{\circ} \mathrm{C}\right)$ & 19.1 & 19.8 & 19.4 & 17.5 & 18.1 & 17.9 & 13.5 & 15.5 & 14.7 & 8.1 & 11.9 & 10.1 \\
\hline Salinity & 33.3 & 33.4 & 33.3 & 34.0 & 34.2 & 34.1 & 33.5 & 33.7 & 33.6 & 32.5 & 33.3 & 32.9 \\
\hline Bottom depth (m) & 16 & 23 & 20 & 33 & 60 & 45 & 74 & 94 & 81 & 47 & 112 & 81 \\
\hline Chlorophyll $a\left(\mu \mathrm{g} \mathrm{L}^{-1}\right)$ & - & - & - & 0.94 & 1.24 & 1.11 & 0.86 & 3.30 & 1.86 & 0.47 & 6.30 & 1.16 \\
\hline Density (ind. $\mathrm{L}^{-1}$ ) & 0.1 & 22 & 11 & ND & ND & ND & 9 & 1872 & 607 & 0.1 & 4 & 1.2 \\
\hline Biomass $\left(\mu \mathrm{g} \mathrm{C} \mathrm{L^{-1 } )}\right.$ & 0.0005 & 0.08 & 0.04 & ND & ND & ND & 0.02 & 2.94 & 0.92 & 0.0002 & 0.04 & 0.002 \\
\hline
\end{tabular}

TABLE 3. - Spearman's correlation coefficients between morphological parameters/abundance of Helicostomella and environmental variables. Significant correlations $(P<0.05)$ are denoted in bold. For St. 1-30, $\mathrm{n}$ (number of stations $)=30$ for abundance values and $\mathrm{n}=27 \mathrm{for}$ morphologic parameters. For St. 6-30, n = 24 (St. 17 excluded from the analyses). St. 1-2 and 3-5 were not analysed separately due to the low number of samples and the non-occurrence of the species, respectively.

\begin{tabular}{|c|c|c|c|c|c|c|c|c|}
\hline & \multicolumn{2}{|c|}{ Temperature } & \multicolumn{2}{|c|}{ Salinity } & \multicolumn{2}{|c|}{ Bottom depth } & \multicolumn{2}{|c|}{ Chlorophyll $a$} \\
\hline & St. $1-30$ & St. 6-30 & St. $1-30$ & St. 6-30 & St. $1-30$ & St. 6-30 & St. $1-30$ & St. 6-30 \\
\hline Oral diameter & -0.22 & -0.76 & -0.30 & -0.80 & -0.14 & -0.50 & -0.55 & -0.63 \\
\hline Total length & 0.44 & -0.39 & 0.07 & -0.41 & -0.67 & -0.53 & -0.30 & -0.37 \\
\hline Collar length & 0.53 & -0.30 & 0.26 & -0.41 & -0.77 & -0.75 & -0.25 & -0.30 \\
\hline Body length & 0.23 & -0.29 & -0.19 & -0.30 & -0.42 & -0.17 & -0.38 & -0.47 \\
\hline Tail length & 0.46 & 0.00 & 0.20 & -0.02 & -0.63 & -0.70 & -0.04 & -0.08 \\
\hline Pedicel length & 0.19 & -0.60 & -0.24 & -0.63 & -0.49 & -0.46 & -0.42 & -0.50 \\
\hline Number of rings & 0.29 & -0.11 & -0.02 & -0.19 & -0.56 & -0.64 & -0.12 & -0.16 \\
\hline Number of denticulate rings & 0.06 & -0.05 & -0.40 & -0.35 & -0.50 & -0.32 & -0.03 & -0.13 \\
\hline Proportion of wrinkled loricae & -0.19 & 0.23 & 0.20 & 0.25 & 0.14 & 0.12 & 0.02 & 0.05 \\
\hline Biovolume & 0.35 & -0.66 & -0.03 & -0.73 & -0.69 & -0.65 & -0.53 & -0.61 \\
\hline Density & 0.25 & 0.84 & 0.26 & 0.77 & 0.45 & 0.33 & 0.42 & 0.57 \\
\hline Biomass & 0.29 & 0.84 & 0.28 & 0.77 & 0.42 & 0.33 & 0.41 & 0.57 \\
\hline
\end{tabular}


TABLE 4. - Morphometric features of Helicostomella spp. and Metacylis annulifera reported in systematic studies subsequent to that of Kofoid and Campbell (1929). Revisions of the suborder Tintinnina (*); ecological studies (+).

\begin{tabular}{|c|c|c|c|c|}
\hline Studied area & Species & Oral diameter $(\mu \mathrm{m})$ & Total length $(\mu \mathrm{m})$ & Reference \\
\hline & H. subulata & $21-23$ & $143-225$ & Kofoid and Campbell, 1929 (*) \\
\hline \multirow{2}{*}{ Mediterranean Sea } & “ & $17-18$ & $83-213$ & Balech, 1959 \\
\hline & “ & $21-26$ & $200-516$ & Marshall, 1969 (*) \\
\hline Brazilian Shelf & “ & $16-18$ & $220-230$ & Souto, $1970 \mathrm{a}$ \\
\hline Brazilian Shelf & “ & $16-17$ & $190-225$ & Souto, $1970 b$ \\
\hline New York Bight, USA & “ & $20-24$ & $119-324$ & Gold and Morales, 1975 (+) \\
\hline Argentine Shelf & “ & $18-21$ & $147-330$ & Souto, 1979 \\
\hline Bahía Blanca Estuary,Argentine & “ & $15-20$ & $129-210$ & Barría de Cao, 1986 \\
\hline Chinhae Bay, Korea & “ & $21-23$ & $178-220$ & Yoo et al., 1988 \\
\hline New England bays, USA & “ & $19-22$ & $153-225$ & Pierce, 1996 \\
\hline North Sea & “ & $23-25$ & $145-225$ & Cordeiro and Sassi, 1997 \\
\hline \multirow[t]{2}{*}{ South Atlantic } & “ & $17-23$ & $50-330$ & Alder, 1999 \\
\hline & “ & $15-30$ & $150-500$ & Strüder-Kypke et al., 2002 \\
\hline Nervión Estuary, Spain & “ & $18-25$ & $60-235$ & Urrutxurtu, $2004(+)$ \\
\hline Argentine shelf & “ & $18-24$ & $56-384$ & Present study \\
\hline Japan Sea & H. subulata "variety" & $18-21$ & $71-82$ & Nakamachi and Iwasaki, 1998 \\
\hline \multirow[t]{6}{*}{ Japan Sea } & H. subulata "typical" & $19-21$ & $151-241$ & Nakamachi and Iwasaki, 1998 \\
\hline & H. kiliensis & $15-19$ & $97-240$ & Kofoid and Campbell, 1929 (*) \\
\hline & H. edentata & $19-24$ & $147-168$ & Kofoid and Campbell, 1929 (*) \\
\hline & H. fusiformis & $20-22$ & $100-180$ & Kofoid and Campbell, 1929 (*) \\
\hline & & $20-29$ & $124-180$ & Marshall, $1969(*)$ \\
\hline & H. longa & $19-22$ & $50-80$ & Kofoid and Campbell, 1929 (*) \\
\hline Tropical East Pacific & “ & $19-23$ & $38-85$ & Kofoid and Campbell, 1939 \\
\hline \multirow[t]{2}{*}{ Chinhae Bay, Korea } & “ & $18-19$ & $70-78$ & Yoo et al., 1988 \\
\hline & M. annulifera & $15-17$ & $60-96$ & Kofoid and Campbell, 1929 (*) \\
\hline Argentine Shelf & “ & $16-17$ & $50-62$ & Balech, 1951 \\
\hline New York Bight, USA & “ & $20-24$ & $49-59$ & Gold and Morales, 1975 (+) \\
\hline Argentine Shelf & “ & $16-20$ & $50-62$ & Souto, 1979 \\
\hline Argentine Shelf & H. lemairei & $19-21$ & $147-194$ & Balech, 1942 \\
\hline South Africa Shelf & H. antarctica & 20 & 112 & Hada, 1970 \\
\hline
\end{tabular}

relation with bottom depth and chlorophyll $a$. When the correlation analysis was instead applied to the 24 stations where Helicostomella showed a similar morphology (St. 6-30, excluding St. 17), significant negative covariations were found to involve all four environmental variables as well as a higher number of morphological parameters, in every case including the oral diameter, the pedicel length and the biovolume. Abundance parameters, in this case, correlated positively with temperature, salinity and chlorophyll $a$ but not with bottom depth.

\section{DISCUSSION}

\section{Taxonomic features of the genus Helicostomella}

Species belonging to the genus Helicostomella Jörgensen, 1924 were rearranged by Kofoid and Campbell (1929), who maintained the hierarchy of H. subulata (Ehrenberg, 1833) Jörgensen, 1924, while raising four variants up to the species level: $H$. edentata (Fauré-Fremiet, 1924), H. fusiformis (Meunier, 1910), H. kiliensis (Laackmann, 1906) and $H$. longa (Brandt, 1906). H. lemairei Balech, 1942 and
H. antarctica Hada, 1970 were later erected. The most relevant systematic investigations on Helicostomella of Argentine shelf waters are those by Balech (1942, 1951) and Souto (1970a,b). These articles were later reviewed by Souto (1979), who reported only two species: $H$. subulata (encompassing $H$. edentata, $H$. fusiformis, $H$. kiliensis and $H$. lemairei as synonyms) and Metacylis annulifera (Ostenfeld and Schmidt, 1901) Kofoid and Campbell, 1929. In a subsequent revision of all available literature on the South Atlantic Ocean including, among others, the works by Brandt (1906-1907) and Kofoid and Campbell (1929, 1939), Alder (1999) maintained Souto's (1979) scheme though also including as synonyms of $H$. subulata the species Tintinnus mediterraneuos var. longa, Tintinnus patagonicus sensu Brandt and Metacylis annulifera, the latter on the basis of the specimens described by Balech (1951). The taxonomic rearrangement of these species was based on the similar morphology of their loricae, the continuity of their length values and, mainly, the fact that the most conservative taxonomic feature within tintinnid lorica, the oral diameter (Laval-Peuto and Bronwlee, 1986; Alder, 1999), does not support keeping them as independent entities. 
TABLE 5. - Densities of Helicostomella spp. and Metacylis annulifera reported by previous ecological surveys. When not provided, mean densities were estimated on the basis of information given by the authors. Observations (OB): studies which covered vertical distribution (V) or only surface/ sub-surface waters (S) and annual cycles (\#).

\begin{tabular}{|c|c|c|c|c|c|c|c|}
\hline Studied area & $\mathrm{OB}$ & $\begin{array}{l}\text { Density } \\
\text { Max }\end{array}$ & $\begin{array}{l}\text { (ind. } \mathrm{L}^{-1} \text { ) } \\
\text { Mean }\end{array}$ & Species & $\begin{array}{l}\text { Oral diameter } \\
\qquad(\mu \mathrm{m})\end{array}$ & $\begin{array}{l}\text { Total length } \\
(\mu \mathrm{m})\end{array}$ & Reference \\
\hline Bedford Basin & V\# & $1 \times 10^{5}$ & 28 & H. subulata & - & - & Paranjape, 1980, 1987 \\
\hline \multirow{3}{*}{$\begin{array}{c}\text { Narragansett Bay } \\
,\end{array}$} & V\# & 5000 & 439 & H. subulata & - & - & Hargraves, 1981 \\
\hline & V\# & 50 & 3 & H. fusiformis & - & - & $"$ \\
\hline & V\# & 100 & 14 & M. annulifera & - & - & $"$ \\
\hline \multirow[t]{2}{*}{ Long Island Sound } & V\# & 30 & 1.4 & H. subulata & 22 & 250 & Capriulo and Carpenter, 1983 \\
\hline & V\# & 26 & 2 & M. annulifera & 21 & 40 & \\
\hline Adriatic Sea & V\# & 420 & 25 & H. subulata & - & - & Kršinić, 1987a \\
\hline Adriatic Sea & V\# & 266 & 22 & H. subulata & - & - & Kršinić, 1987b \\
\hline Maine Estuary & $\mathrm{S} \#$ & 2500 & 191 & H. subulata & - & - & Sanders, 1987 \\
\hline \multirow[t]{2}{*}{ Gulf of Trieste } & V\# & 2100 & - & H. subulata "smaller" & $15-18$ & $50-76$ & Lipej, 1992 \\
\hline & V\# & 264 & - & H. subulata "normal" & $18-20$ & $150-241$ & \\
\hline \multirow{4}{*}{ Hiroshima Bay } & $\mathrm{V}$ & 700 & 92 & H. longa & - & - & Kamiyama, 1995 \\
\hline & V\# & - & 0.6 & H. subulata & - & - & Kamiyama and Tsujino, 1996 \\
\hline & V\# & 500 & 1.9 & H. fusiformis & - & - & \\
\hline & V\# & 1600 & 4.4 & H. longa & - & - & $"$ \\
\hline Baltic Sea & $\mathrm{S} \#$ & 1200 & 31 & H. subulata & - & - & Wasik and Mikolajczyc, 1996 \\
\hline Uruguayan Shelf & $\mathrm{S}$ & 2 & 1 & H. subulata & $19-20$ & $160-230$ & Fernandes, 1998 \\
\hline Adriatic Sea & V\# & 300 & 65 & H. subulata & - & - & Bojanić, 2001 \\
\hline Chesapeake Bay & V & $<10$ & - & H. subulata & - & - & Dolan and Gallegos, 2001 \\
\hline \multirow{2}{*}{ Vellar Estuary, India } & $\mathrm{S} \#$ & 250 & - & H. longa & - & - & Godhantaraman, 2002 \\
\hline & $\mathrm{S} \#$ & 250 & - & H. fusiformis & - & - & \\
\hline \multirow[t]{2}{*}{ Gulf of Naples } & V\# & 28720 & 123 & H. subulata & $16-20$ & $80-190$ & Modigh and Castaldo, 2002 \\
\hline & V\# & 160 & 183 & M. annulifera & $14-18$ & $55-75$ & \\
\hline \multirow{3}{*}{$\begin{array}{l}\text { Lagoon system of Japan } \\
\quad,\end{array}$} & V\# & 500 & - & H. subulata & - & - & Godhantaraman and Uye, 2003 \\
\hline & V\# & 500 & - & H. fusiformis & - & - & $"$ \\
\hline & V\# & 1000 & - & H. longa & - & - & $"$ \\
\hline Sea of Marmara & $\mathrm{S} \#$ & 160 & 22 & H. subulata & - & - & Balkis, 2004 \\
\hline Baltic Sea & V\# & 1383 & 98 & H. subulata & 18 & 70 & Johansson et al., 2004 \\
\hline Salento Peninsula & V\# & 6066 & - & H. subulata & - & - & Moscatello et al., 2004 \\
\hline Adriatic Sea & V\# & 3975 & - & H. subulata & - & - & Bojanić et al., 2006 \\
\hline \multirow[t]{2}{*}{ Tokio Bay } & S \# & 12000 & 345 & H. subulata & - & - & Nakane et al., 2008 \\
\hline & $\mathrm{S} \#$ & 49000 & 504 & H. longa & - & - & \\
\hline Argentine shelf & $\mathbf{S}$ & 1872 & 143 & H. subulata & $18-24$ & $56-384$ & Present study \\
\hline
\end{tabular}

Tables 4 and 5 comprise the data available for different sectors of the world ocean referred to systematic and ecological surveys describing and/or reporting Helicostomella species, respectively. From this information it can be observed that the seven species previously reported for the genus Helicostomella and $M$. annulifera have an oral diameter normally ranging between 15 and 26 $\mu \mathrm{m}$, and a highly variable total length (50 to 400 $\mu \mathrm{m}$, with only two reports of individuals reaching higher values). The loricae morphologically and statistically examined in this work (Fig. 3 and 4) showed a practically constant oral diameter (18-24 $\mu \mathrm{m})$ and a continuous range for total length (56-384 $\mu \mathrm{m})$, which includes almost all values previously reported for the longest $(H$. subulata, H. kiliensis, $H$. fusiformis, H. edentata, H. lemairei and $H$. antarctica) and shortest taxa (H. longa and $M$. annulifera). Among the entire list of studies included in Tables 4 and 5, only two adopted the differentiation of morphotypes for $H$. subulata, such as Normal and Smaller (Lipej, 1992), or Typical and Variety
(Nakamachi and Iwasaki, 1998), in correspondence with long and short loricae, respectively. If we assume that the development of this species is comparable to that of the morphologically analogous Favella ehrenbergii (which was studied under culture conditions; Laval-Peuto, 1981), fluctuations in total length would be a consequence of life cycle and of the influence of environmental factors. These results support the postulate that morphological parameters restrain the separation of the mentioned species as independent taxonomic entities, and thus that all of them are included within $H$. subulata (Alder, 1999). Such an assumption, however, needs to be supported by the assessment of the environmental factors possibly affecting the morphology of the loricae (see below) and further cytological and/or molecular analyses. While Protargol staining has revealed a relatively constant infraciliature pattern in specimens of $H$. subulata with a total length between 153 and $225 \mu \mathrm{m}$ (Pierce, 1996), individuals below or above this size range still require detailed examination. 


\section{Methodological considerations and general distribution of $\boldsymbol{H}$. subulata}

Abundance estimations of tintinnids are mostly based either on large volumes of water $(>100 \mathrm{~L})$ concentrated by means of sieves/nets with a 20 $30 \mu \mathrm{m}$ pore size or on smaller volumes $(0.5-5 \mathrm{~L})$ of non-filtered, settled water (Alder, 1999). In this work both methodologies were tested on Helicostomella, revealing that: (1) The use of small volumes of non-filtered water highly disregards fluctuations in abundance; low actual densities may lead to the false conclusion that the species is absent (such was the case in more than half the area examined). (2) Filtration affects abundance estimations, even in the case of a mesh pore $(20 \mu \mathrm{m})$ slightly smaller than the mean oral diameter $(20.5 \mu \mathrm{m})$; however, such a bias falls well within the same order of magnitude as the estimation itself and thus should not be considered as an obstacle for assessing the real distribution patterns and abundance levels of the organism.

Although actual densities of any shell-bearing protozoan should be based strictly on the counting of cells, practically all abundance estimations of foraminiferans, radiolarians and tintinnids are based on the number of shells. In the particular case of tintinnids, this practice is even more frequent, as the cell is usually lost during sampling and/or fixation (Alder, 1999). Our study includes a detailed analysis not only of the relative contribution of cell-bearing, cyst-bearing and empty loricae to density, but also of the biovolume variations between the sites sampled, leading to the conclusion that the longer the loricae, the greater the probability of the cell being retained inside. Because of the lack of previous reports on this issue, and despite the considerable amount of information gathered on this occasion, we can not state whether the individuals counted were alive at the time of collection.

While previous quantitative studies covering adjacent estuaries (Barría de Cao, 1986; Kogan, 2005) or oceanic waters (Fernandes, 1998; Thompson et al., 2001; Thompson and Alder, 2005) have revealed only occasional occurrences of $H$. subulata in very low concentrations, we detected its presence in practically the entire Argentine shelf (Fig. 6B). These observations agree with the neritic distribution reported all around the world for Helicostomella spp. and M. annulifera (Pierce and Turner, 1993; Tables 4 and 5). Since these taxa commonly prevail in the upper $10 \mathrm{~m}$ of the water column (Paranjape,

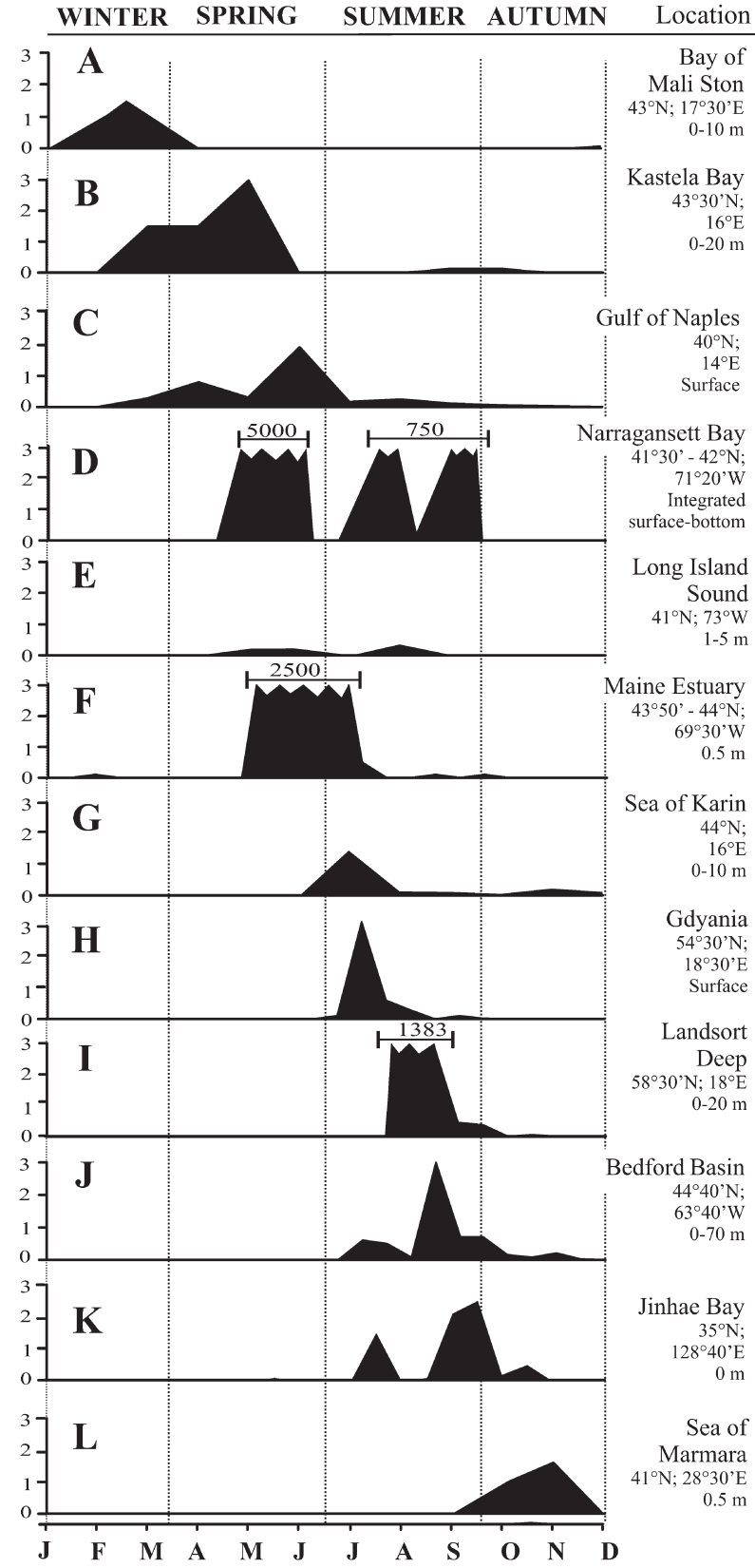

Fig. 8. - Temporal density fluctuation of Helicostomella spp. and Metacylis annulifera (A-L: $10^{2}$ ind. $\mathrm{L}^{-1}$, except for $\mathrm{J}$ and $\mathrm{K}$ : $10^{3}$ ind. $\mathrm{L}^{-1}$ ) in neritic marine environments from previous studies which include detailed information about annual cycles. A, B, G, H, J and K: modified from Kršinić (1987a), Bojanić (2001), Kršinić (1987b), Wasik and Mikolajczyk (1996), Paranjape (1987) and Kim et al. (2007), respectively. C, D, E, F, I and L: graphs built from data sets provided by Modigh and Castaldo (2002), Hargraves (1981), Capriulo and Carpenter (1983), Sanders (1987), Johansson et al. (2004) and Balkis (2004), respectively. D, E, F: only monthly highest values. D, H, I: no information available for winter. D, F, I: numbers over the profiles correspond to maximum density (ind. $\mathrm{L}^{-1}$ ).

1980; Kršinić, 1987a; Kamiyama, 1995; Bojanić, 2001), the 9 m-depth waters sampled during our study are assumed to represent quite accurately the real abundance of $H$. subulata. Highest densities 
found during our work fall within the same order of magnitude as those historically registered for the species (Table 5), excluding exceptional values of $10^{4}$ and $10^{5}$ ind. $\mathrm{L}^{-1}$ (Paranjape, 1980, 1987; Modigh and Castaldo, 2002; Nakane et al., 2008). As far as biomass is concerned, although no previous records are available for $H$. subulata, our calculations based on Lipej's (1992) data yielded a maximum value similar to that reported here (ca. $3 \mu \mathrm{g} \mathrm{C} \mathrm{L}^{-1}$ ).

Despite differences in methodological criteria and environmental settings, previous temporal analyses of Helicostomella spp. and M. annulifera (Table 5, Fig. 8) show density values strongly influenced by water temperature and seasonality, generally peaking between ca. 10 and $20^{\circ} \mathrm{C}$ during spring and/or summer (Fig. 8B-K), but only occasionally in winter (Fig. 8A) or autumn (Fig. 8L). No detailed information is available on annual cycles for the southern hemisphere, but the latitudinal trend found for $H$. subulata on the Argentine shelf seems to confirm previous results: highest abundances occur between $45^{\circ} \mathrm{S}$ and $53^{\circ} \mathrm{S}$ in summer (Santoferrara, 2007), and between $42^{\circ} \mathrm{S}$ and $45^{\circ} \mathrm{S}$ in autumn (present study), in coincidence with temperatures of 11 to $15^{\circ} \mathrm{C}$. The northward displacement of the species maxima is noted to follow the seasonal fluctuations of chlorophyll concentration: because of the latitudinal changes in temperature and light, south of $45^{\circ} \mathrm{S}$ the phytoplanktonic bloom is delayed and lasts until summer (Romero et al., 2006), in accordance with highest mean chlorophyll $a$ and $H$. subulata concentrations found during this season $\left(4.3 \mu \mathrm{g} \mathrm{L}^{-1}\right.$ and 595 ind. $\mathrm{L}^{-1}$, respectively; Santoferrara, 2007). In contrast, north of $45^{\circ} \mathrm{S}$, the bloom is restricted to spring, with secondary increases in autumn, thus suggesting that the mean values found for the latter season $\left(2.4 \mu \mathrm{g} \mathrm{L}^{-1}\right.$ and 607 ind. $\left.\mathrm{L}^{-1}\right)$ may be lower than those of spring.

The disappearance of $H$. subulata during the cold season and its re-emergence in the warm period (Fig. $8 \mathrm{~B}-\mathrm{K}$ ) is thought to be due to encystment and excystment processes, respectively (Paranjape, 1980). The environmental conditions triggering the periodic cyst formation are poorly known, but plausible explanations include temperature control and bottom-up/top-down regulations (Paranjape, 1980; Müller, 2000). Depletion of food sources due to phytoplankton bloom decay, increased predation pressure and high temperature during summer may also lead to the encystment of the species, a phenomenon that is probably more common than expected and could take place as a short-scale response to environmental stress. On the other hand, it is accepted that the excystment of Helicostomella is regulated by light and temperature (Kamiyama and Aizawa, 1992) and promoted by the availability of nanophytoplankton or phytoplanktonic extracellular products (Kamiyama, 1994, 1997).

\section{Variations in the lorica morphology and abundance of Helicostomella in Argentine shelf waters}

The environmental and ecological heterogeneity of Argentine shelf waters made it possible to identify four sectors with differences in the quali-quantitative distribution of $H$. subulata. All of these sectors were found to be limited by physicochemical gradients which are consistent with reported oceanographic front positions (Fig. 5, 6 and 7, Tables 1 and 2).

The northernmost sector is located in Buenos Aires coastal waters (St. 1 and 2), and corresponds to the inner, mixed side of El Rincón front (Fig. 1 and 6 ), which separates typical shelf waters from those diluted by riverine discharge (Acha et al., 2004). It exhibited the highest temperatures and the lowest bottom depth values within the area investigated (see Table 2). The correlations between morphological and environmental variables based on the entire data set (Table 3) are assumed to be affected by the longest individuals recorded in this sector: several length-related parameters (total length, collar, tail, pedicel), as well as the number of rings and the biovolume, were detected to increase significantly towards shallow waters. In the case of the collar length, this increase (which was particularly notable: over four times) was also associated with higher temperatures. These trends, in combination with the occurrence of relatively low numbers of individuals (a relatively common situation, as can be gathered from the review of previous studies: Capriulo and Carpenter, 1983; Lipej, 1992; Fernandes, 1998; Godhantaraman and Uye, 2003; see Table 5), suggest that some particular conditions of this kind of environment, such as the permanent mixing of the water column and the predominance of microplanktonic diatoms and thecate dinoflagellates, result in Helicostomella investing energy in growth in size rather than in reproduction.

A second sector was distinguished in the vicinity of San Matías Gulf (St. 3-5), where H. subulata showed a clear distribution gap (Fig. 6B) and the 
highest salinities (average: 34.1; Table 2, Fig. 6C) occurred as a result of the water outflow from the gulf (Piola and Rivas, 1997). Previous reports of the species in both oligohaline (Godhantaraman, 2002) and highly saline environments (Kršinić, 1987a,b; Bojanić et al., 2006), however, suggest that salinity has a minor influence on the species distribution. Grazing pressure does not explain the absence of the species in this sector either, since crustacean densities recorded for the austral autumn are generally low (Ramírez, 1996). On the other hand, although chlorophyll $a$ concentrations in this sector were relatively high (mean: $1 \mu \mathrm{g} \mathrm{L}^{-1}$; Fig. 6C, Table 2), we observed that the phytoplanktonic assemblage was dominated by the microplanktonic diatoms Leptocylindrus danicus, Rhizosolenia styliformis and Chaetoceros compressus (unpublished data), which do not seem to constitute a suitable food source for this species (H. subulata feeds mainly on pico- and nanoplankton; Bernard and Rassoulzadegan, 1993; Dolan et al., 2002). Therefore, neither the environmental factors analysed (Table 2) nor the bibliography revised (Table 5) offered a satisfactory explanation for the absence of the species between the El Rincón and Valdés fronts (Fig. 6B and C).

South of the San Matías Gulf system, typical subAntarctic waters extend approximately from $42^{\circ} \mathrm{S}$ to the southern end of the shelf $\left(55^{\circ} \mathrm{S}\right)$. Such an ample latitudinal range encompasses strong differences in both environmental conditions and the abundance of Helicostomella (Fig. 6B and 7). Within this vast area there is a differentiation between the richer and warmer northern Patagonian waters (St. 6-12), which include the stratified side of the Valdés front (Acha et al., 2004; Bianchi et al., 2005), and the poorer and colder southern Patagonian waters (St. 13-30), which include those of lowest salinity due to the strong input of diluted waters entering from the Pacific through the Strait of Magellan and via the Cape Horn Current. This trend is also supported by the negative correlations found for the abundance of Helicostomella vs. temperature, salinity and chlorophyll $a$ (Table 3 ). In contrast with the significance gained by bottom depth when the whole transect is considered, this variable does not seem to affect Helicostomella numbers in the Patagonian region, probably because of the uniformity in the bottom depths covered by the study (Table 2). In addition, the collar length of the individuals collected within this latitudinal range covaried inversely with bottom depth and salinity, thus indicating the major contri- bution of rings to total length in low-salinity, shallow waters.

In northern Patagonian waters, the highest abundances of $H$. subulata (Fig. 6B) were entirely represented by short loricae. A review of the existing literature covering this topic shows that this trend was observed for other marine environments as well (Lipej, 1992; Kamiyama, 1995; Godhantaraman and Uye, 2003; Johansson et al., 2004; see Table 5) and that it may be attributed to excystment (Paranjape, 1980). On this basis, taking into consideration the above discussion on the seasonality of $H$. subulata, it can be speculated that excystment must have occurred during the beginning of the austral autumn, as supported also by the presence of cysts in this sector and by some favourable conditions for this process: (1) the temperature range $\left(13.5-15.5^{\circ} \mathrm{C}\right.$; Table 2 ) includes the value which triggers the excystment of some loricate and aloricate ciliates $\left(15^{\circ} \mathrm{C}\right.$; Kamiyama and Aizawa, 1992; Kim and Taniguchi, 1995), and partially overlaps with that known to favour high growth rates in $\mathrm{H}$. subulata (up to $4 \mathrm{~d}^{-1}$ at $12-14^{\circ} \mathrm{C}$; Paranjape, 1980); (2) these waters host the maximum mean chlorophyll $a$ concentration (ca. $2 \mu \mathrm{g} \mathrm{L}^{-1}$; Table 2, Fig. 6C) jointly with high picoplankton and nanoplankton densities (Alder and Franzosi, 2003; Almandoz et al., 2007), denoting the availability of both an adequate food source and phytoplanktonic extracellular products. Enhanced excystment and reproduction would lead to an increase in the number of short loricae, a strategy suggested also for other tintinnids (Gold and Morales, 1975) and aimed at maintaining the bulk of the population within the euphotic layer. The role of $H$. subulata in this kind of environment, as derived from the above considerations, confirms the relevance of the species as a trophic link within certain neritic food webs (Bojanić et al., 2006).

The last sector corresponds to southern Patagonian waters (St. 13-30), where H. subulata showed the same lorica morphology as in northern Patagonian waters (except at St. 17), but mean density and biomass values were lower by two orders of magnitude (Fig. 6B, Table 2). This decrease followed a rather uniform path, and is therefore not thought to be due (at least exclusively) to top-down regulation: the high biomass reported for copepods in this sector during autumn show a patchy distribution (Sabatini and Âlvarez Colombo, 2001). Instead, inadequate conditions of temperature and food availability seem to be the most plausible explanation, since: (1) 
densities dropped below 1 ind. $\mathrm{L}^{-1}$ in waters under $10^{\circ} \mathrm{C}$ (Fig. 6B and C), in correspondence with the temperatures of the autumn-winter decline of the species in other temperate and cold environments (Gold and Morales, 1975; Capriulo and Carpenter, 1983; Sanders, 1987; Wasik and Mikolajczyk, 1996; Balkis, 2004; Johansson et al., 2004); and (2) the mean chlorophyll $a$ concentration was ca. 50\% lower (Table 2), excluding the maximum found in the transition zone between the two sectors. In view of these conditions, it is likely that the extremely low densities of $H$. subulata recorded in southern Patagonian waters during the austral autumn are due to an encystment process that advances northward and reaches its highest intensity in winter.

Finally, at one particular site of the last sector (St. 17), the loricae of $H$. subulata showed lengths which were intermediate between those of St. 1-2 and the rest. Given the proximity of St. 17 to the inner, mixed waters of the Cabo Blanco tidal front (Bianchi et al., 2005; Fig. 6B), these loricae could be responding to a situation similar to that observed at El Rincón front in the sense that the production of longer loricae is enhanced by the conditions typical of the homogenous side of fronts. Nevertheless, there are clear divergences in the behaviour of the two fronts that would lead to somehow different responses in $H$. subulata: like other Patagonian tidal fronts, Cabo Blanco is strongly influenced by the seasonal dynamics of the shelf, while El Rincon represents a quasi-permanent estuarine phenomenon (Acha et al., 2004). Considering that estuarine fronts can act as a barrier for the dispersion of planktonic species (Largier, 1993), the dynamics of El Rincon, followed by the distributive gap at San Matías Gulf, could lead to the isolation of two subpopulations of $H$. subulata from Buenos Aires and Patagonian waters.

\section{CONCLUSION}

In Argentine shelf waters, along ca. fourteen degrees of latitude, we found practically the complete range of previously reported variability for the lorica of Helicostomella species and M. annulifera. From the strictly morphological point of view, both the continuity of values within each examined feature and the constancy of the oral diameter lead us to conclude that the morphological variations detected fall within the intraspecific polymorphism of $H$. subulata, which should also include M. annulifera. Major fluctuations in the total length are attributed to the contribution of the collar (on average 50\%), which seems to increase in length in shallower, warmer and less saline waters, by adding rings in numbers that decrease from the north to the south following the latitudinal fluctuation in temperature.

This species tends to develop a longer lorica when growing in permanently mixed waters (often in the vicinity of fronts) dominated by microplanktonic cells, and a shorter one when inhabiting deeper, stratified waters, which generally involve a different quality of food resources. Optimum conditions during the austral autumn correspond to those found in northern Patagonian waters, where the species reaches its highest concentrations and its smallest size of lorica (probably due to excystment). There is evidence that in this sector $H$. subulata plays a key role in the transfer of matter and energy from smaller to larger planktonic organisms. On the other hand, the low temperatures and chlorophyll $a$ concentrations of southern Patagonian waters seem to trigger the reduction of the species density due to encystment.

The joint assessment of morphological features and the spatial distribution and abundance of this species allowed us to characterise four different environments within Argentine shelf waters and to detect a phenomenon of disjunct distribution of $H$. subulata: the species was totally absent from $41^{\circ} \mathrm{S}$ to $42^{\circ} \mathrm{S}$, probably due to the unfavourable conditions of waters near to San Matías gulf, an environment which seems to constitute a natural barrier, dividing the populations from the adjacencies of El Rincón front $\left(40-40.5^{\circ} \mathrm{S}\right)$ and Patagonian waters (42.5-54.5 $\left.{ }^{\circ} \mathrm{S}\right)$ which, despite the constancy of the oral diameter, differ significantly (three-fold) as to all length-related parameters of the lorica. These results highlight the need to perform combined systematic (morphological, cytological, genetic) studies to determine whether significant length differences represent two forms of the life-cycle or phenotypic adaptations of a single species, or just independent, reproductively isolated species, and also to test whether oral diameter is a valid diagnostic character for the classification of the genus Helicostomella.

\section{ACKNOWLEDGEMENTS}

We are thankful to Lic. Visbeek for technical assistance in the installation of the sampling system, to 
Lic. Olguín Salinas for his help in the identification of diatom species, to Lic. Kocmur for analysing nutrient samples, and to the members of the ARGAU Project for making abiotic data available. Two anonymous reviewers contributed with helpful comments that improved the manuscript. This work was supported by a fellowship granted to L.S. by the Consejo Nacional de Investigaciones Científicas y Técnicas, and by grants to V.A. from the same institution (PIP 0246), the Agencia Nacional de Promoción Científica y Tecnológica (PICT 7-9108), and the Instituto Antártico Argentino (Proyecto $\mathrm{N}^{\circ} 58$ ).

\section{REFERENCES}

Acha, E., H. Mianzán, R. Guerrero, M. Favero and J. Bava. - 2004 Marine fronts at the continental shelves of austral South America. Physical and ecological processes. J. Mar. Sist., 44: 83-105.

Agatha, S. and M. Strüder-Kypke. - 2007. Phylogeny of the order Choreotrichida (Ciliophora, Spirotricha, Oligotrichea) as in ferred from morphology, ultrastructure, ontogenesis, and $\mathrm{SSr}-$ RNA gene sequences. Eur. J. Protistol., 43(1): 37-63.

Alder, V. - 1999. Tintinnoinea. In: D. Boltovskoy (ed.), South At lantic zooplankton, pp. 321-384. Backhuys Publishers, Leiden.

Alder, V. and C. Franzosi. - 2003. Bacterioplankton abundance in relation to environmental factors in the Argentine Sea during April 2002. Proc. IBMANT/ ANDEEP Int. Symp., Argentina.

Almandoz, G., M. Ferrario, G. Ferreyra, I. Schloss, J. Esteves and F. Paparazzo. - 2007. The genus Pseudo-nitzschia (Bacillariophyceae) in continental shelf waters of Argentina (Southwestern Atlantic Ocean, $38-55^{\circ}$ S). Harmful Algae, 6: 93-103.

Balech, E. - 1942. Tintinnoideos del estrecho Le Maire. Physis, XIX: 245-252

Balech, E. - 1951. Nuevos datos sobre Tintinnoinea de Argentina y Uruguay. Physis, 20(58): 291-302.

Balech, E. - 1959. Tintinnoinea del Mediterráneo. Trab. Inst. Esp. Oceanogr., 28: 1-84

Balkis, N. - 2004. Tintinnids (Protozoa: Ciliophora) of the Büyükcekmece Bay in the Sea of Marmara. Sci. Mar., 68(1): 33-44.

Barría de Cao, S. - 1986. Contribución al conocimiento de Tintinnina (Protozoa, Ciliophora) de la zona de Bahía Blanca, II (Argentina). Bol. Inst. Esp. Oceanogr., 3(1): 143-150.

Bernard, C. and F. Rassoulzadegan. - 1993. The role of picoplankton (cyanobacteria and plastidic picoflagellates) in the diet of tintinnids. J. Plankton Res., 15(4): 361-374.

Bianchi, A., L. Bianucci, A. Piola, D. Ruiz Pino, I. Schloss, A. Poisson and C. Balestrini. - 2005. Vertical stratification and airsea $\mathrm{CO}_{2}$ fluxes in the Patagonian shelf. J. Geophis. Res., 110: C07003, doi: 10.1029/2004JC002488.

Bojanić, N. - 2001. Seasonal distribution of the ciliated protozoa in Kastela Bay. J. Mar. Biol. Ass. U.K., 81: 383-390.

Bojanić, N., M. Šolić, N. Krstulović, S. Sestanović, Z. Ninčević Gladan, I. Marasović and I. Brautović. - 2006. The role of ciliates within the microbial food web in the eutrophicated part of Kastela Bay (middle Adriatic Sea). Sci. Mar., 70(3): 431-442.

Boschi, E. - 1998. El Mar Argentino y sus recursos pesqueros, Vol. 2. INIDEP, Mar del Plata.

Capriulo, G. and E. Carpenter. - 1983. Abundance, species composition and feeding impact of tintinnid microzooplankton in central Long Island sound. Mar. Ecol. Prog. Ser., 10: 277-288.

Cordeiro, T. and R. Sassi. - 1997. Tintinnina (Ciliophora, Protista) of the North Sea during the spring of 1986. Helgol. Meeresunters, 5: $155-172$.

Dolan, J. and C. Gallegos. - 2001. Estuarine diversity of tintinnids (planktonic ciliates). J. Plankton Res., 23(9): 1009-1027.

Dolan, J., H. Claustre, F.Carlotti, S. Plounevez and T. Moutin. 2002. Microzooplankton diversity: relationship of tintinnid cili- ates with resources, competitors and predators from the Atlantic Coast of Morocco to the Eastern Mediterranean. Deep-Sea Res. Part I, 49: 1217-1232.

Fernandes, L. - 1998. Taxonomia, distribuicao e biomassa dos tintininos (Ciliophora, Tintinnina) e microplâncton associado no Atlântico Sul Ocidental. Ph.D. thesis, Univ. Paraná.

Field, J., K. Clarke and R. Warwick. - 1982. A practical strategy for analysing multispecies distribution patterns. Mar. Ecol. Prog. Ser. 8: 37-52

Godhantaraman, N. - 2002. Seasonal variations in species composition, abundance, biomass and estimated production rates of tintinnids at tropical estuarine and mangrove waters, Parangipettai region, southeast coast of India. J. Mar. Syst., 36: 161-171.

Godhantaraman, N. and S. Uye. - 2003. Geographical and seasonal variations in taxonomic composition, abundance and biomass of microzooplancton across a brackish-water lagoonal system of Japan. J. Plankton Res., 25(5): 465-482.

Gold, K. and E. Morales. - 1975. Seasonal changes in lorica sizes and the species of Tintinnina in the New York Bight. J. Protozool., 22(4): 520-528.

Hada, Y. - 1970. The protozoan plankton of the Antarctic and Subantarctic seas. Jare Scientific Reports Series 31, National Science Museum, Tokyo.

Hargraves, P. - 1981. Seasonal variation of tintinnids (Ciliophora: Oligotrichida) in Narragansett Bay, Rhode Island, USA. $J$. Plankton Res., 3(1): 81-91.

Johansson, M., E. Gorokhova and U. Larsson. - 2004. Annual variability in ciliate community structure, potential prey and predators in the open northern Baltic Sea proper. J. Plankton Res., 26: 67-80.

Kamiyama, T. - 1994. Effects of extracellular products from phytoplankton on the excystment of tintinnids from marine sediments. Mar. Ecol. Prog. Ser., 105: 199-201.

Kamiyama, T. - 1995. Change in the microzooplankton community during decay of a Heterosigma akashiwo bloom. J. Oceanogr., 51: 279-287.

Kamiyama, T. - 1997. Effect of phytoplankton abundance on excystment of tintinnid ciliates from marine sediments. J. Oceanogr., 53: 299-302.

Kamiyama, T. and Y. Aizawa. - 1992. Effects of temperature and light on tintinnid excystment from marine sediments. Nippon Suisan Gakk, 58: 877-844.

Kamiyama, T. and M.Tsujino. - 1996. Seasonal variation in the species composition of tintinnid cilates in Hiroshima Bay, the Seto Inland Sea of Japan. J. Plankton Res., 18(12): 2313-2327.

Kim, Y-O. and A. Taniguchi. - 1995. Excystment of the oligotrich ciliate Strombidium conicum. Aquat. Microb. Ecol., 9: $149-156$.

Kim, S., M. Gil Park, C. Moon, K. Shin and M. Chang. - 2007. Seasonal variations in phytoplankton growth and microzooplankton grazing in a temperate coastal embayment, Korea. Est. Coast. Shelf Sci., 71: 159-169.

Kofoid, C. and A. Campbell. - 1929. A conspectus of the marine and freshwater Ciliata belonging to the suborder Tintinnoinea, with description of new species principally from the Agassiz Expedition to the Eastern Tropical Pacific 1904-1905. Univ. Calif. Publ. Zool., 34: 1-403.

Kofoid, C. and A. Campbell. - 1939. Reports on the scientific results of the expedition to the Eastern Tropical Pacific. The Ciliata: the Tintinnoinea. Bull. Mus. comp. Zool. Harvard Univ., 34: $1-473$.

Kogan, M. - 2005. Estudio de la composicón especifica, abundancia y distribución espacial del microzooplancton en el estuario del Río de La Plata. Ph.D. thesis, Univ. Buenos Aires.

Kršinić, F. - 1987a. On the ecology of tintinnines in the bay of Mali Ston (Eastern Adriatic). Est. Coast. Shelf Sci., 24(4): 401-418.

Kršinić, F. - 1987b. Tintinnines (Ciliophora, Oligotrichida, Tintinnina) in eastern Adriatic bays. Est. Coast. Shelf Sci., 24(4): $527-538$.

Largier, J. - 1993. Estuarine fronts: how important are they? Estuaries, 16(1): 1-11.

Laval-Peuto, M. - 1981. Construction of the lorica in Ciliata Tintinnina. In vivo study of Favella ehrenbergii: variability of the phenotypes during the cycle, biology, statistics, biometry. Protistologica, 17(2): 249-272.

Laval-Peuto, M. and D. Bronwlee. - 1986. Identification and systematics of the Tintinnina (Ciliophora): evaluation and sugges- 
tion for improvement. Ann. Inst. Oceanogr., 62(1): 69-84.

Lipej, L. - 1992. The tintinnid fauna (Tintinnina, Choreotrichida, Ciliophora) in Slovenian coastal waters. Razprave IV, Razreda Sasu, XXXIII(4): 93-113.

Marshall, S. - 1969. Protozoa Order Tintinnida. In: J. Fraser and V. Hansen (eds.), Fishes d' identification du zooplancton. Cons. Per. Int. Explor. Mer., Charlottenlund, 120: 1-6.

Modigh, M. and S. Castaldo. - 2002. Variability and persistence in tintinnid assemblages at a Mediterranean coastal site. Aquat. Microb. Ecol., 28: 299-311.

Moscatello, S., F. Rubino, O. Saracino, G. Fanelli, G. Belmonte and F. Boero. - 2004. Plankton biodiversity around the Salento Peninsula (Southeast Italy): an integrated water/ sediment approach. Sci. Mar., 68(1): 85-102.

Müller, H. - 2000. Evidence of dormancy in planktonic oligotrich ciliates. Verh. Internat. Verein. Limnol., 27: 3206-3209.

Nakamachi, M. and N. Iwasaki. - 1998. List of tintinnids (Protozoa: Ciliata) in Uranouchi Inlet, Kochi, Japan. Bull. Mar. Sci. Fish., Kochi Univ., 18: 65-76.

Nakane, T., K. Nakaka, H. Bouman, T. Platt. - 2008. Environmental control of short-term variation in the plankton community of inner Tokyo Bay, Japan. Est. Coast. Shelf Sci., 78: 796-810.

Paranjape, M. - 1980. Occurrence and significance of resting cysts in a hyaline tintinnid Helicostomella subulata (Ehre.) Jorgensen. J. Exp. Mar. Biol. Ecol., 48: 23-33.

Paranjape, M. - 1987. Seasonal cycle and vertical distribution of tintinnids in the Bedford Basin, Nova Scotia, Canada. Can. J. Zool., 65(1): 41-48.

Pierce, R. - 1996. Morphology and infraciliature of selected species of Tintinnina with a philogenetic analysis of the Tintinnina based on infraciliature. Ph.D. thesis, Univ. Rhode Island.

Pierce, R. and J. Turner. - 1992. Ecology of planktonic ciliates in marine food webs. Rev. Aquat. Sci., 6(2): 139-181.

Pierce, R. and J.Turner. - 1993. Global biogeography of marine tintinnids. Mar. Ecol. Prog. Ser., 94: 11-26.

Piola, A. and A. Rivas. - 1997. Corrientes en la plataforma continental. In: E. Boschi (ed.), El mar argentino y sus recursos pesqueros. Antecedentes históricos de las exploraciones en el mar y las características ambientales. Vol. 1, pp. 119-132. Publicaciones Especiales INIDEP, Mar del Plata.

Ramírez, F. - 1996. Composición, abundancia y variación estacional del zooplancton de red del golfo San Matías. Frente Marit., 16(A): $157-167$.

Romero, S., A. Piola, M. Charo and C.Garcia. - 2006. Chlorophylla variability off Patagonia based on SeaWiFS data. J. Geophys. Res., 111: C05021, doi:10.1029/2005JC003244.

Sabatini, M. and G. Álvarez Colombo. - 2001. Seasonal pattern of zooplankton biomass in the Argentinian shelf off southern Patagonia $\left(45^{\circ}-55^{\circ} \mathrm{S}\right)$. Sci. Mar., 65(1): 21-31.

Sabatini, M. and P. Martos. - 2002. Mesozooplankton features in a frontal area off northern Patagonia (Argentina) during spring 1995 and 1998. Sci. Mar., 66(3): 215-232.

Sanders, R. - 1987. Tintinnids and other microzooplankton-seasonal distributions and relationships to resources and hydrography in Maine estuary. J. Plankton Res., 9(1): 65-77.

Santoferrara, L. - 2007. Estudio sistemático y ecológico de los ciliados (Protista, Ciliophora) planctónicos del Mar Argentino y Pasaje Drake. Ph.D. thesis. Univ. Buenos Aires.

Souto, S. - 1970a. Tintinnidos de la costa brasilera colectados por el Walther Herwig (Protozoa, Ciliata). Physis, XXX(80): 209-224.

Souto, S - 1970b. Tintinnidos de la costa atlántica entre los $31^{\circ}$ y $35^{\circ}$ de latitud sur (Uruguay y sur de Brasil) (Protozoa, Ciliata). Physis, XXX(80): 187-208.

Souto, S. - 1979. Tintínnidos del Atlántico Sudoccidental y Antártida Argentina (Protozoa, Ciliata). Estudio taxonómico, distribucional y ecológico. Ph.D. thesis, Univ. Buenos Aires.

Strickland, J. and T. Parsons. - 1972. A practical handbook of seawater analysis. J. Fish. Res. Board. Can., 167: 1-311.

Strüder-Kypke, M., E. Kypke, S. Agatha, J. Warwick and D. Montagnes. - 2002. The user-friendly guide to coastal planktonic ciliates. http://www.liv.ac.uk/ciliate/site/pages/h_subu/.

Thompson, G. and V. Alder. - 2005. Patterns in tintinnid species composition and abundance in relation to hydrological conditions of the Southwestern Atlantic during austral spring. Aquat. Microb. Ecol., 40: 85-101.

Thompson, G., V. Alder and D. Boltovskoy. - 2001. Tintinnids (Ciliophora) and other microzooplankton in Southwestern Atlantic Shelf break waters. Mar. Ecol., 22(4): 343-355.

Urrutxurtu, I. - 2004. Seasonal succession of tintinnids in the Nervión River estuary, Basque Country, Spain. J. Plankton Res., 26(3): 307-314.

Utermöhl, H. - 1958. Zur vervolkommung der quantitativen phytoplankton-methodik. Mitt. Int. Ver. Theor. Angew. Limnol., 9: $1-38$.

Verity, P. and C. Langdon. - 1984. Relationship between lorica volume, carbon, nitrogen, and ATP content of tintinnids in Narragansett Bay. J. Plankton Res., 6: 859-868.

Wasik, A. and E. Mikolajczyc. - 1996. The seasonal succession of hyaline Helicostomella subulata and aglutinated Tintinnopsis lobiancoi-dominants of the Baltic Tintinnina (Ciliophora). Oceanologia, 38(3): 405-418.

Yoo, K-I., Y-O. Kim and D-Y. Kim. - 1988. Taxonomic Studies on Tintinnids (Protozoa: Ciliata) in Korean Coastal Waters. 1. Chinhae Bay. Korean J. Syst. Zool., 4(1): 67-90.

Scient. ed.: D. Vaqué.

Received September 3, 2008. Accepted January 29, 2009.

Published online July 6, 2009. 